\title{
$40 \mathrm{~kW}$ Stirling engine for solid fuel
}

\section{Carlsen, Henrik; Trærup, Jens; Ammundsen, Niels}

\section{Published in:}

Proceedings of the 31st Intersociety Energy Conversion Engineering Conference

Link to article, DOI:

10.1109/IECEC.1996.553904

Publication date:

1996

\section{Document Version}

Publisher's PDF, also known as Version of record

Link back to DTU Orbit

Citation (APA):

Carlsen, H., Trærup, J., \& Ammundsen, N. (1996). $40 \mathrm{~kW}$ Stirling engine for solid fuel. In Proceedings of the 31st Intersociety Energy Conversion Engineering Conference (pp. 1301-1306). IEEE.

https://doi.org/10.1109/IECEC.1996.553904

\section{General rights}

Copyright and moral rights for the publications made accessible in the public portal are retained by the authors and/or other copyright owners and it is a condition of accessing publications that users recognise and abide by the legal requirements associated with these rights.

- Users may download and print one copy of any publication from the public portal for the purpose of private study or research.

- You may not further distribute the material or use it for any profit-making activity or commercial gain

- You may freely distribute the URL identifying the publication in the public portal

If you believe that this document breaches copyright please contact us providing details, and we will remove access to the work immediately and investigate your claim. 


\title{
40 kW STIRLING ENGINE FOR SOLID FUEL
}

\author{
Henrik CARLSEN, Dept. for Energy Engineering \\ Technical University of Denmark \\ DK-2800 Lyngby \\ PHONE (+45) 45254171, FAX (+45) 45930663 \\ Niels AMMUNDSEN, Vølund R\&D Centre \\ Centervej 2 \\ DK-6000 Kolding, Denmark \\ PHONE (+45) 75568874, FAX (+45) 75568873 \\ Jens TRERUP, REKA A/S \\ Vestvej 7 \\ DK-9600 Års, Denmark \\ PHONE (+45) 98624011, FAX (+45) 98624071
}

\section{ABSTRACT}

The external combustion in a Stirling engine makes it very attractive for utilisation of solid fuels in decentralised combined heat and power (CHP) plants.

Only few projects have concentrated on the development of Stirling engines specifically for biomass. In this project a Stirling engine has been designed primarily for utilisation of wood chips. Maximum shaft power is $40 \mathrm{~kW}$ corresponding to an electric output of $36 \mathrm{~kW}$.

Biomass needs more space in the combustion chamber compared to gas and liquid fuels, and a large heat transfer area is necessary. The design of the new Stirling engine has been adapted to the special demands of combustion of wood chips, resulting in a large engine compared to engines for gas or liquid fuels.

The engine has four-cylinders arranged in a square. The design is made as a hermetic unit, where the alternator is built into the pressurised crankcase so that dynamic seals are avoided. Grease lubricated bearings are used in a special designed crank mechanism, which eliminates guiding forces on the pistons. Helium is used as working gas at $4 \mathrm{MPa}$ mean pressure.

The first test of the $40 \mathrm{~kW}$ engine with natural gas as fuel has been made in the laboratory, and the results are in agreement with predicted results from simulation programs. The wood chips combustion system has been tested for some time with very promising results. When the laboratory test of the engine is finished, the test of the complete system will be initiated.

The paper describes the engine and results from the test program. Expectations to maintenance and operation problems are also discussed

\section{INTRODUCTION}

The external combustion in a Stirling engine makes it very attractive for utilisation of solid fuels in small scale CHP plants. However, only few projects have concentrated on the development of Stirling engines specifically for this purpose.

Running a Stirling engine on solid fuel like wood chips or coal is more complicated than using gas or liquid fuel, because the content of ash and other particles in the combustion products results in fouling of the narrow passages between the tubes and the fins in the heater (Baumüller, 1996). Therefore, a Stirling engine for solid fuel has to be adapted to the demands of the solid fuel combustion system.

An increased interest in small scale heat and power production based on biomass resulted in the initiation of the project described below. The objective of the project was to develop a stationary Stirling engine for electric power generation, which is specifically designed to utilise solid fuels, such as wood chips, straw or other sorts of biomass.

\section{STIRLING ENGINE LAY'OUT}

A four-cylinder, double acting design was chosen for the new Stirling engine. The target shaft power was $40 \mathrm{~kW}$ at an efficiency above $20 \%$ based on lower heat content of the biomass fuel. Wood chips was chosen as fuel for the first prototype as the content of ash is small and the melting point of the ash is high compared to that of straw. Also the content of corrosive components such as chlorine and alkali metals are low in wood chips. Thereby the problems of high temperature corrosion, that occurs in straw fired steam plants are avoided.

Solid fuels require mulh more space in the combustion chamber compared to gas or oil, because combustible particles take some time to burn out. Furthermore, the distance between tubes and fins in the heat transfer section 
must be large in order to avoid slag particles from fouling the convection heat transfer area. Utilisation of solid fuels therefore results in a hot heat transfer section (heater), which is much larger than normally used in conventional Stirling engines.

The heater section is designed for a heat transfer rate of 50 $\mathrm{kW}$ per $\mathrm{m}^{2}$ corresponding to common practice in biomass steam plants. The design of the Stirling engine has then been adapted to the dimensions of the heater, resulting in a less compact design compared to automotive Stirling engines.

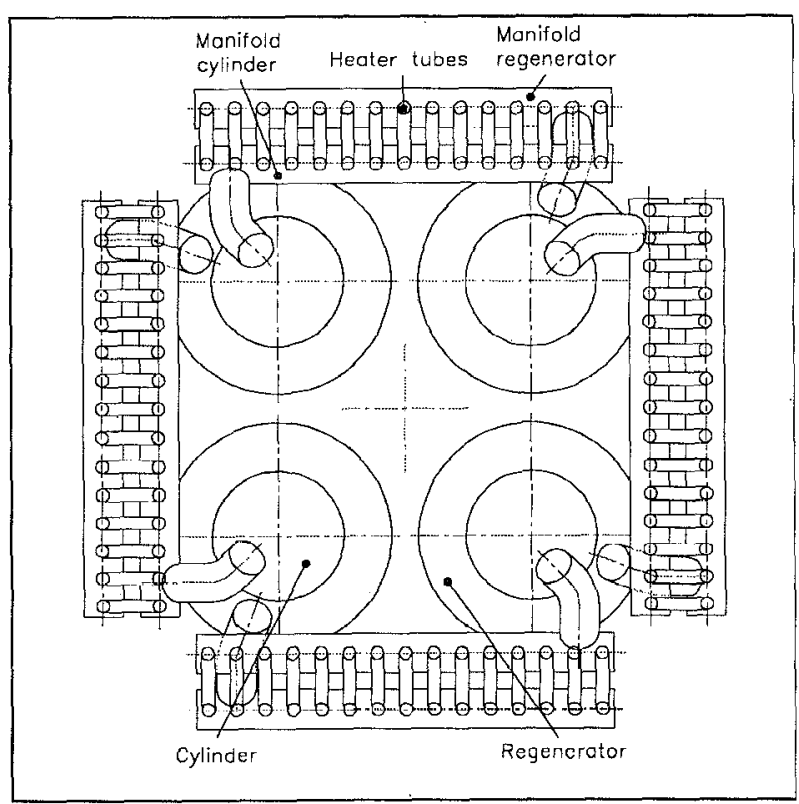

FIG. 1. Schematic heater section.

Based on the experience from a single cylinder test engine (Carlsen 1993), the new engine is designed as a hermetic unit just like a hermetic compressor for refrigeration. The alternator is incorporated in the pressurised crank casing. Only static seals are necessary and the only connections to the surroundings are the cable connection to the grid. Oil in the crank casing is eliminated by utilisation of grease lubricated needle and ball bearings.

No piston rods or rotating cranks penetrate the pressure boundary containing the pressurised working gas. The demands on piston rod seals are reduced drastically in this way and the rod seals can be quite simple, as small leaks between the cylinder volumes and crankcase can be tolerated. Static O-ring seals are used to keep the pressurised helium from leaking to the atmosphere.

Figure 2 shows a draft of the design and figure 3 shows the engine without combustion chamber. The four cylinders are arranged in a square with cylinders parallel to each other. The asynchronous alternator, which is used as a starter motor too, has 6 poles corresponding to an engine speed of $1015 \mathrm{rpm}$ when coupled directly to the grid $(50 \mathrm{~Hz} \mathrm{AC})$. Helium is used as working gas at $4 \mathrm{MPa}$ mean pressure.
A special crank mechanism based on the well known Ross mechanism eliminates the guiding forces on the cross heads. This is necessary when there is no oil in the crank casing. Grease lubricated needle and roller bearings are used and the calculated lifetime of the bearings is 40.000 hours.

Regenerators and coolers are placed concentric to the piston/cylinder, sharing the same pressure vessel. Coolers are tube and shell type, where the working gas flows inside the thin tubes, while the cooling water flows outside the tubes in an annular chamber. The regenerator is made directly from stainless steel thread.

The hot cylinder volume is connected through the heater to the volume above the regenerator in the cylinder next to it as shown in figure 1 . The inner row of the four heater sections form the radiation part of a square combustion chamber $(0,55$ $\times 0,55 \times 0,25 \mathrm{~m}$ ), while the outer tube row of each heater has fins for improved convective heat transfer. The characteristic dimensions of tubes and fins in the heater are chosen so that the risk of fouling is minimised.

The engine has valves connecting the compression volumes and the pressurised crank casing. When the valves are open, the two volumes are connected and the variations of the pressure in the working volume will be very small. The alternator will then be working as a motor rotating the Stirling engine. If the valves are closed the engine will be running at full load.

An engine for CHP will normally run 5000 - 6000 hours per year at full load. Service intervals must be kept at a minimum, as service is a considerable cost in small CHP plants. To meet these demands the wearing parts of the Stirling engine have been designed for long lifetimes. The bearings are expected to last for at least 50.000 hours, and the

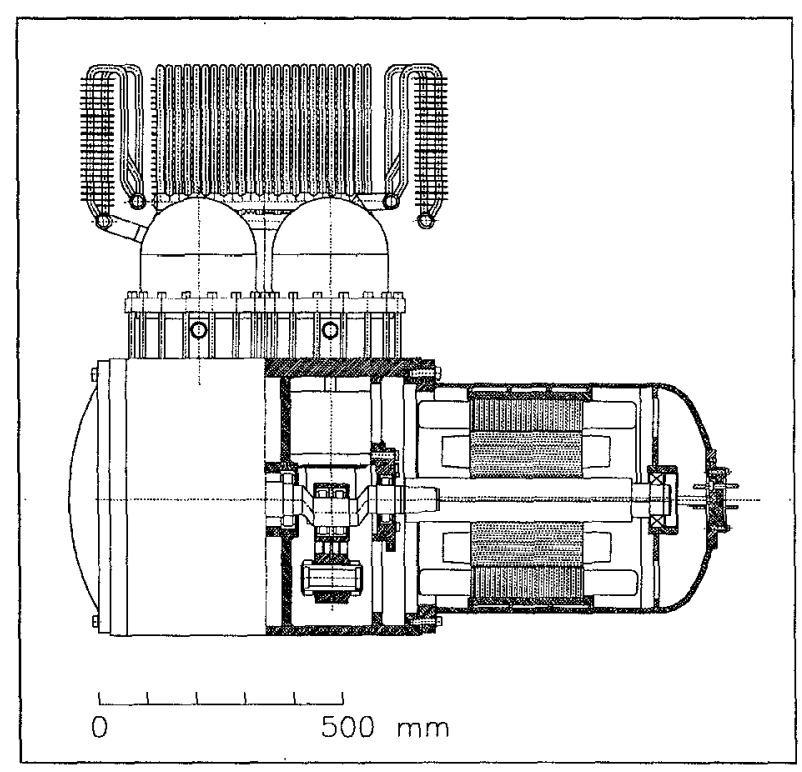

FIG. 2, Draft of the $40 \mathrm{~kW}$ engine. 


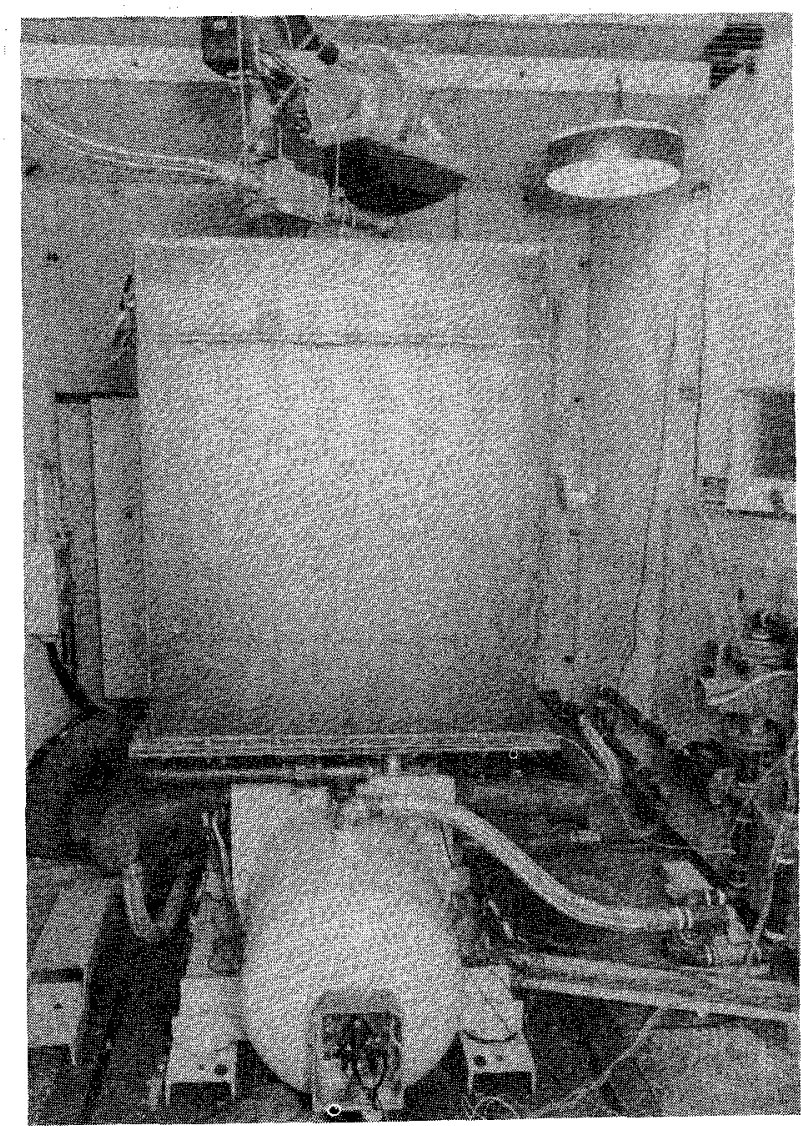

FIG. 3. Test of engine with gas burner.

\section{TABLE 1. Specifications}

$\begin{array}{ll}\text { Shaft output, kW } & 40 \\ \text { Bore, mm } & 140 \\ \text { Stroke, mm } & 74 \\ \text { Number of cylinders } & 4 \\ \text { Speed, rpm } & 1015 \\ \text { Mean pressure, Mpa } & 4.0 \\ \text { Working gas } & \text { Helium } \\ \text { Max. heater temp., K } & 953 \\ \text { Engine weight, kg } & 1200 \\ \text { Engine-length, m } & 1.3 \\ \text { width, m } & 0.8 \\ \text { height, m } & 1.2\end{array}$

piston and piston rod seals and the guiding rings, which are made from PFTE-materials, are expected to last for 10.000 hours. Service intervals are expected to be 10 times longer than the 1.000 hours interval between service for internal combustion engines.

\section{COMBUSTION SYSTEM}

The design of the combustion system is based on a commercially available furnace system for wood chips, which has been further developed for the application of the Stirling engine.

Wood chips are stored in a silo with hydraulic scrapers. Transport screws are used for moving the wood chips from the silo to a weighing machine and further on to the stoker through a cell lock. The cell lock is necessary in case of burn back. The weighing machine has only been included for accurate measurement of the wood chips consumption.

Figure 4 shows a sketch of the combustion system. A screw feeds the wood chips to a high temperature revolving grate in a well insulated combustion chamber. The Stirling engine is mounted upside down on top of the insulated combustion chamber, so that radiation from the combustion is transferred to the heater. The design of the combustion chamber is made so that the flue gases changes direction flowing from the combustion chamber to the Stirling engine heater section. In this way larger particles are separated before they enter theStirling engine heater section

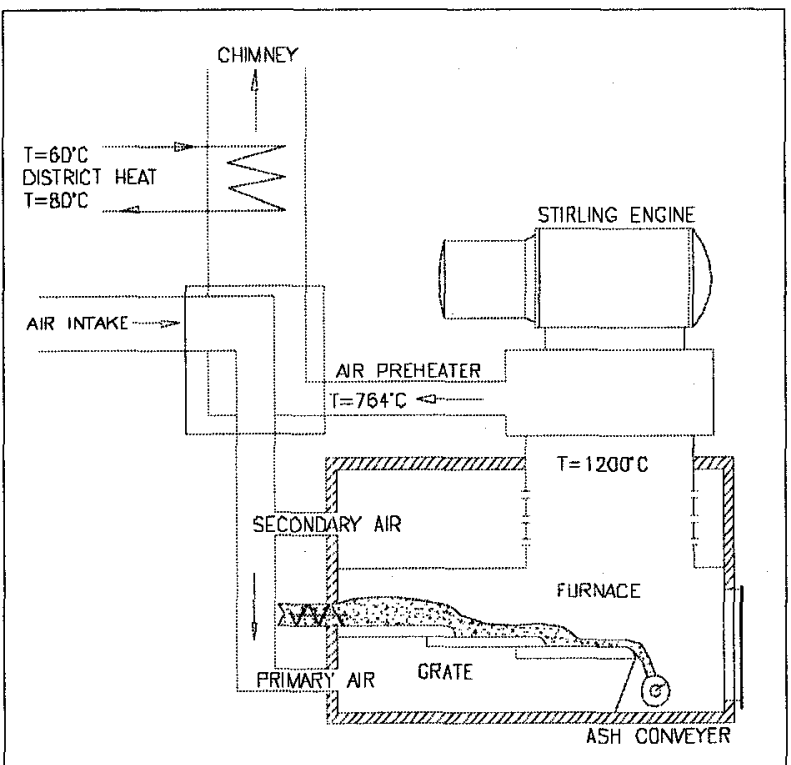

FIG. 4. Sketch of wood chips system including Stirling engine.

After the passage of the heater head the temperature of the flue gas is approximately $760^{\circ} \mathrm{C}$ before it enters the air preheater and finally the after cooler before it is conducted to the chimney. Primary air is supplied under the grate and secondary air is added just before the mix of flue gas and combustible gases enters the heater section, this is done to insure a good flame radiation at the radiation parts of the heater. The combustion air is preheated to approximately $600^{\circ} \mathrm{C}$.

Initially the temperature control system was based on an ordinary on/off control known from furnaces. This was insufficient as fluctuations in heater tube temperature were too large. The control system therefore had to be improved, 
and a new strategy including more accurate speed control of the screws and blowers was developoed.

\section{PLANT OPERATION}

The $40 \mathrm{~kW}$ Stirling engine for biomass is aiming at the market for small CHP plants in villages, at large farms and institutions situated in rural environments. The heat produced by the plant will be distributed in a district heating system and the electric power will be transmitted to the public grid.

To keep the operating costs at a minimum, small scale plants will have to run in unmanned operation for days or weeks. To meet this demand the system has been fully automated. Controls of the combustion system and the engine are separated. The control system for the Stirling engine, which also monitors the electric production and the gris, is based on a standard system developed for grid connection of windmills. In case of any disturbances or emergencies the system will automatically shut down.

A typical start up of the plant will be as follows. The fire on the grate is started manually. When the heater tube temperature passes $400^{\circ} \mathrm{C}$ the alternator will start automatically and rotate the Stirling engine. The valves controlling the power will be kept open until the alternator reaches its working rotational speed. After the valves have closed, engine power increase as the heater temperature rises. When the operating temperature of $680^{\circ} \mathrm{C}$ is reached, the temperature control takes over, in order to maintain the desired temperature level.

If any malfunctions occur in the combustion system, and the heat production fails, the engine will be turned of when the heater temperature has reached the level, where the engine has stopped producing power. Any engine failure will be detected by the engine electronics and the combustion system will immediately be shut down.

\section{TEST RESULTS}

The Stirling engine and the combustion system have been tested separately. The Stirling engine has been tested with a commercially available blower burner for natural gas, which was mounted on a simple combustion chamber with ceramic fibre insulation. An air preheater was not included in the test system and the efficiency of the complete natural gas fired Stirling engine has not been recorded.

The initial tests were made with different helium mean pressures and heater tube temperatures. Results from the tests are shown on figure 5 . The figure shows the shaft power as a function of hot temperature at three different mean pressures corresponding to $2.2 \mathrm{Mpa}, 3 \mathrm{Mpa}$ and $4.3 \mathrm{MPa}$. Temperature of the cooling water from the engine is $35^{\circ} \mathrm{C}$.

Figure 6 shows the engine efficiency as a function of hot temperature at the same mean pressures as above. The engine efficiency $\eta_{\text {eng }}$ is not an over all efficiency; but it has been calculated from an energy balance based on the heat output and the electric power output from the engine:

$$
\begin{aligned}
& \eta_{\text {eng }}=P_{\text {shaft }} /\left(P_{\text {shaft }}+Q_{\text {cooling }}\right) \\
& P_{\text {shaft }}=\mathrm{P}_{\mathrm{e}} / \eta_{\text {gen }}
\end{aligned}
$$

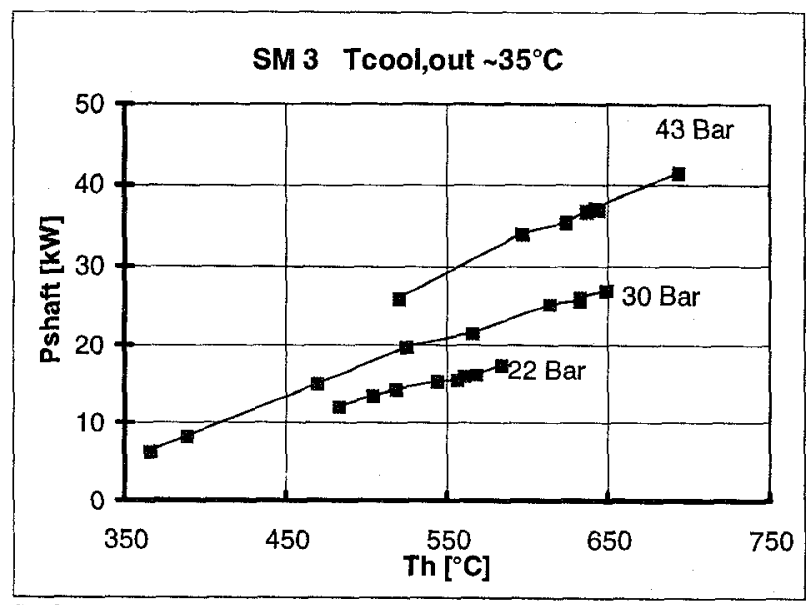

FIG. 5. Engine power at three different mean pressures.

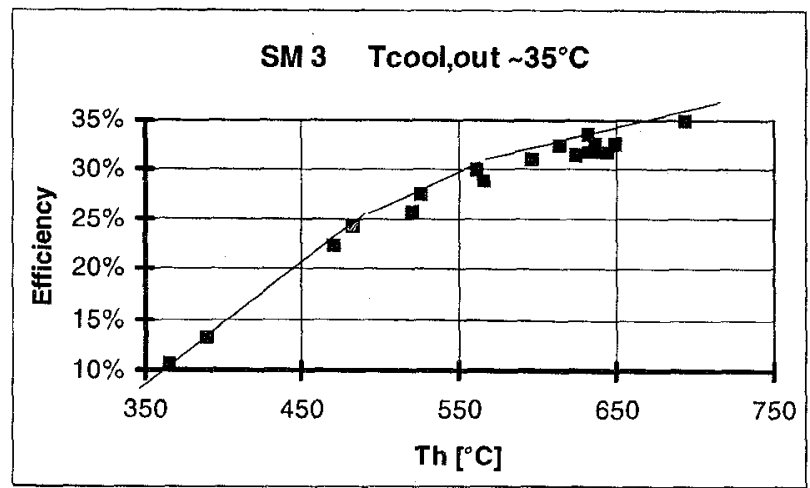

FIG. 6. Engine efficiency for the same run as above.

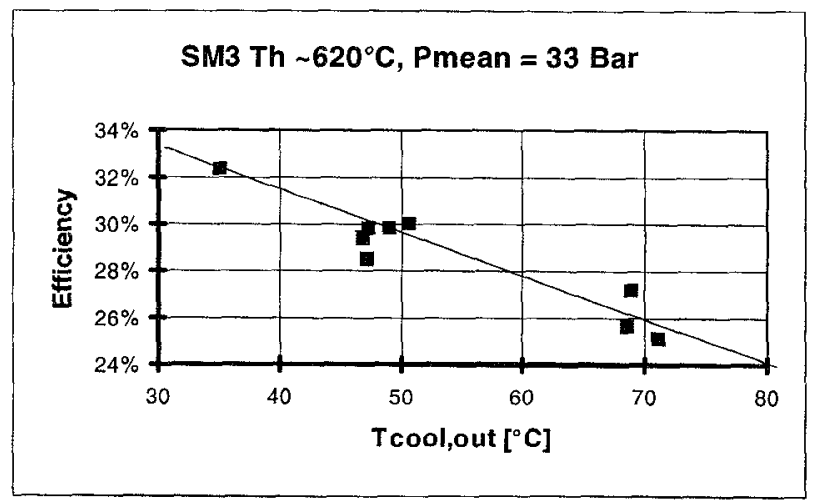

FIG. 7. Engine efficiency as a function of cold temperature.

The efficiency of the generator is specified by the supplier to $\eta_{\text {gen }}=91 \%$. Q water. $\eta_{\text {eng }}$ can be regarded as an engine efficiency exclusive losses in the burner system. The results from all tests at different temperatures and pressures are shown, and it can be seen that the efficiency without burner is nearly proportional 
to the heater tube temperature and independent of the pressure. The engine efficiency is approximately $35 \%$ at full load.

Figure 7 shows the engine efficiency as defined above as function of the temperature in the cooling water from the engine at reduced heater heat temperature $\left(620^{\circ} \mathrm{C}\right)$. It can be seen, that the efficiency decreases significantly as a function of the cold temperature.

Initial tests of the combustion system have been made with a dummy heater installed instead of the Stirling engine. The dummy heater is cooled by pressurised air, and temperatures on the heater tubes are controlled within the same limits as for the Stirling engine.

One of the difficulties in using wood chips instead of gas or oil in a Stirling engine is, that it is more complicated to establish an accurate control of the temperature on the heater tubes. Changes in the quality and humidity of the wood chips and fluctuations in the feeding result in variations in the power input, which are not a problem in a furnace, but in a Stirling engine the resulting changes in temperature are unacceptable.

Numerous adjustments of the control system have been made. The numbers below show the result obtained:

-Heater tube temperature could be controlled within $+/-5^{\circ}$.

-Oxygen content of the flue gas is controlled within $2 \%$ to $5 \%$.

-CO emission is very low indicating a good combustion.

Figure 8 show results from tests at stationary conditions. The amount of heat transferred into the dummy heater is 115 $\mathrm{kW}$ corresponding to the demand from the engine producing $40 \mathrm{~kW}$ of shaft power at $35 \%$ engine efficiency.

Table 2: Plant specifications:

$\begin{array}{lc}\text { Electric power, } \mathrm{kW}_{\mathrm{el}} & 36 \\ \text { Plant consumption, } \mathrm{kW}_{\mathrm{el}} & 2 \\ \text { District heat at } 65^{\circ} \mathrm{C}, \mathrm{kW} & 102 \\ \text { Wood chips consumption, } \mathrm{kg} / \mathrm{h} & 55 \\ \text { Electric efficiency } & 0,21 \\ \text { Overall efficiency } & 0,85\end{array}$

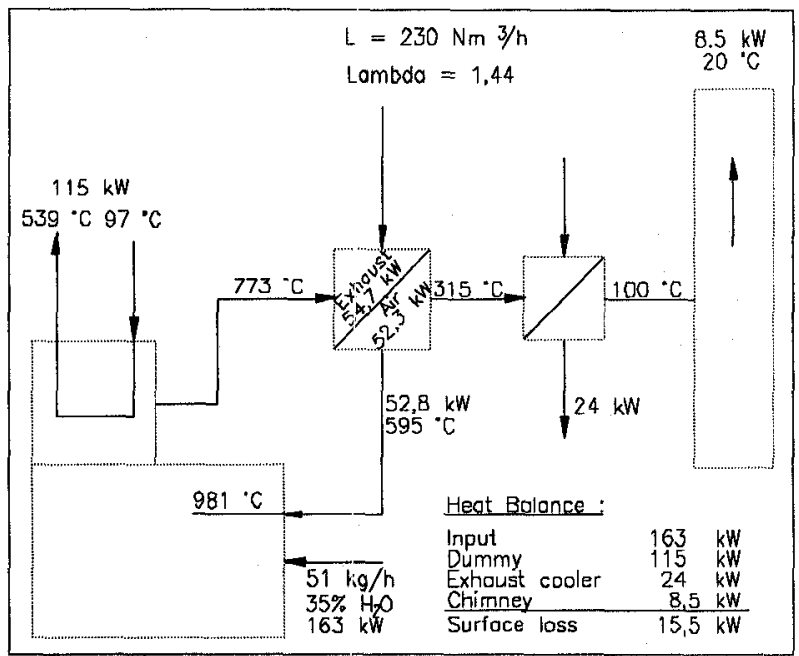

FIG. 8. Combustion system at stationary conditions

Results from a 200 hour test have been very promising. Slagging of the heater tubes and fins was less than expected and the reduction of heat transfer was insignificant. The slag was porous and it could easily be removed.

A farm in northern Denrnark is the host for the test of the combustion system. When the tests are finished the dummy heater will be replaced by the Stirling engine, and the complete system will be set in to operation for a two year field test. The heat produced by the plant will be distributed in a district heating systenn in the village, where the farm is situated. The electric power will be transmitted to the public grid.

Table 2 shows the plant specifications. The "overall efficiency" is the sum of electric and heat output compared to the heat content in the fuel input.

\section{CONCLUSION}

A new Stirling engine has been developed primarily for utilisation of wood chips in small combined heat and power plants. The semi-hermetic design of the engine has several advantages for stationary Stirling engines with electric power output, as problems with leaks and severe wear of rod seals etc. are eliminated. A new crank mechanism eliminating the need for oil in the crankcase has shown to be very suitable for the purpose.

The engine and the wood chips combustion system have been tested separately with very promising results. The engine has been tested in the laboratory using natural gas as fuel. The results show that the engine is capable of producing the predicted power of $36 \mathrm{~kW}_{\text {electric }}$ at an engine efficiency of $35 \%$.

A 200 hour test of the combustion system showed, that the heat to the Stirling engine can be transferred in the heater without causing problems with slagging and that the heater tube temperature can be controlled within $+/-5^{\circ}$. 
Initial tests of the combustion system and the engine indicate, that the chosen design will fulfil the expectations to efficiency and reliability.

\section{ACKNOWLEDGEMENT}

The project is funded by the Danish Energy Agency and ELKRAFT AmbA and it is carried out as a co-operation between Technical University of Denmark and the companies Vølund Danstoker A/S, REKA A/S and PlanEnergi A/S.

\section{REFERENCES}

Baumüller, A. 1996,"Anwendung und Märkte für stationäre Stirlingmaschinen heute - Aufbau der Heizkraft-Module und Solarmaschinen auf basis des SOLO Stirling 161," Paper presented at the "European Stirling forum 1996" in Osnabrück, Germany.

Carlsen, H. "10 kW Hermetic Stirling Engine for Stationary Applications", 6th International Stirling Engine Conference, Eindhoven, Holland, ISEC-93 086, 6p.

Carlsen, $\mathrm{H}$ "Operating experience with a $10 \mathrm{~kW}$ hermetic Stirling Engine", 29th Intersociety Energy Conversion Engineering Conference, Monterey CA, USA, August 1994, $6 \mathrm{p}$. 